\title{
"THE SPIRIT": LEFT OUT AND THEN \\ REINTRODUCED? A STUDY OF COLOSSIANS 3:16 AND EPHESIANS 5:18-19 IN THE CONTEXT OF THE AUTHORSHIP DEBATE
}

\author{
J. Gertrud Tönsing \\ Department of Biblical and Ancient Studies \\ University of South Africa
}

\begin{abstract}
This article aims to formulate a new hypothesis on the authorship debate concerning the disputed letters Colossians and Ephesians. It argues that the letters were co-written with Paul by his co-workers in order to make Paul's theology more acceptable to the congregations. Colossians omits controversial Pauline terms, but Ephesians corrects this and tries to reintroduce Pauline theology in a way that will build unity in the churches. A particular parallel text, the study of which sparked this research, is discussed to see if this hypothesis makes sense both of the similarities but also the differences between the two letters.
\end{abstract}

Keywords: Ephesians; Colossians; authorship; early Christian worship; "Spirit" in Pauline texts

\section{Introduction}

This article aims to give a new explanation for a difficult question in New Testament scholarship: What are the reasons for both the similarities and the differences between the two disputed Pauline letters, Colossians and Ephesians? How do they relate to each other, and to the undisputed letters, especially to the letter to Philemon, which shares most of its greeting list with Colossians? Is there an explanation which helps to interpret closely related texts in the two letters?

This research was sparked by the study of the two passages on worship: Colossians 3:12-17 and Ephesians 5:15-21. These passages, particularly the verses which speak of singing "psalms, hymns and spiritual songs" (Col 3:16 and Eph 5:18-19), have long held interest for scholars of early Christian worship and contemporary liturgical practitioners (e.g. Costa 2013:216-217). These texts are debated as to whether they are a plea for diversity in worship and what guidance they may give to present worship debates. In this context, the similarities and differences between the two texts, which are obviously closely related, are of interest. For example, the South African pastor and hymn writer Hugh Wetmore highlights the emphasis of the Colossians text on the "Word" and that of Ephesians on the term "Spirit". He argues that the one text appeals more to "Reformed" worshipers, who focus on the Word, and the other to "Pentecostal" worshipers, who focus on the Spirit, but that the same appeal to be open to diversity in worship is made to both (Wetmore 2012 [online]). "Reformed" and "Pentecostal" are of course anachronistic labels for early Christian texts. However, the observation does raise the interesting 
question of the relationship between these two texts and why they are almost verbally the same in some places, yet clearly different in others. Scholars point out that "Holy Spirit" is not mentioned in Colossians (Schweizer 1976:22), though the word "spiritual" is used, as in the text above. ${ }^{1}$ This is one of the factors in the arguments disputing Pauline authorship. However, although Ephesians draws heavily on Colossians, the Holy Spirit is mentioned repeatedly in Ephesians (see later discussion). Does this make it a more "Pentecostal" letter and what could the reason be for this difference?

The questions which led to this research arise from the discussions around worship in contemporary congregational praxis. However, this article wants to engage these questions from the perspective of the ongoing debates around the interpretation of Colossians and Ephesians, particularly the authorship question. From the point of view of worship practitioners, these debates probably seem irrelevant. However, new insights in scholarship can enrich worship practice and perhaps prevent the misuse of texts for purposes for which they were not intended.

\section{Methodology}

The interpretation of the two letters is centrally linked to the question of authorship. In this study a traditional historical critical method will be followed which discusses various authorship hypotheses to see how well they explain the characteristics of the letters in front of us. While many questions have been raised about the possibility of gaining an "objective" view of the past and whether this is even relevant (see discussion on methods in Davies 2013:2), it is argued here that the authorship question and the historical debates are still relevant and perhaps there are answers that have not yet been considered. Different hypotheses on authorship obviously also lead to different explanations of authorial intention and possible meaning of the texts.

The two letters belong to the disputed Pauline letters, and scholars are divided about whether they are Pauline or Deutero-Pauline. The relevance of this discussion will be briefly argued, and then the different positions in the authorship debate will be summarised and weighed up against each other. This article aims to formulate a hypothesis on the authorship debate which could make sense of the characteristics of the letters of Colossians and Ephesians, as well as their relationship to the undisputed letters of Paul, especially the letter to Philemon. This hypothesis will then be taken as starting point in the interpretation of the two texts, to test whether it can offer a plausible explanation of the differences between the texts and their probable intention. In conclusion, the interpretation will be briefly related to contemporary worship discussions.

\section{Authorship debate - Colossians The need to consider this question}

The two letters Ephesians and Colossians belong to the group of letters of which Pauline authorship is disputed. Some scholars argue that both are Pauline (McKnight 2018:5-18, O'Brien 1982:xli-xlix), others that only Colossians is Pauline and Ephesians is based on

$\pi v \varepsilon \tilde{v} \mu \alpha$ occurs only once in Colossians, in 1:8 ( $\dot{\varepsilon} v \pi v \varepsilon v ́ \mu \alpha \tau 1)$, according to Schweizer to distinguish spiritual from worldly love (1976:39). $\pi v \varepsilon v \mu \alpha \tau \kappa \tilde{n}$ also occurs in Col 1:9. 
Colossians (Hooker 2003:1404), and others that both are post-Pauline (Pokorny 1987:217 and Lohse 1968:254). The debate has raged for many years and seems no closer to being resolved, though it does seem that the majority of scholars are in favour of postPauline authorship (Pervo 2010:60). ${ }^{2}$

When interpreting a particular passage, it is fair to question whether it is even necessary to resolve the issue. The early church accepted both letters as canonical and thus their instructions as authoritative for Christians (Porter and Clarke 1997:70; McFarland 2000:345). In daily use in congregations no distinction is made between "genuine" and "pseudepigraphal" letters. In a discussion about worship in a congregation this distinction would not need to be made. In biblical scholarship in general there is also a shift towards more interest in the text as it stands or in the way the reader receives the text, and disregard of issues of authorship. ${ }^{3}$ However, in New Testament studies generally, the undisputed Pauline letters undoubtedly carry much greater weight in the discussions on the development of early Christian theology. Many discussions on the theology and thought of Paul do not reference the disputed letters at all, except as point of contrast or pointing out future developments. ${ }^{4}$ In this context, an interpretation of these passages cannot avoid at least considering the authorship question and its implications regarding the intention of the passages.

Most scholars argue that Ephesians is an expanded letter which draws on Colossians, rather than Colossians being a shorter version of Ephesians. This position has been argued convincingly many times (Hay 2000:22, Schnackenburg 1982:27-29) ${ }^{5}$ and will not be elaborated on here. For this reason, Colossians will be discussed first in this article.

\section{The case against Pauline authorship of Colossians}

The earliest suggestion that Colossians and Ephesians may not have originated with Paul was made by Mayerhoff in 1838 (Wolter 1993:27). Since then more scholars have agreed with the general assessment that Colossians is so different from other Pauline letters both in language and style and in its concepts that it is at least questionable whether it was written by Paul himself.

There is consensus about the fact that the typical polemical, argumentative style of Paul is absent (Wolter 1993:29) and there are many words and grammatical structures (such as consecutive genetives or infinitives) which are not typical of the undisputed Pauline letters. In Colossians 34 words are hapaxlegomena (appearing only here), another 25 are shared only with Ephesians and a further 28 only with 2 Thessalonians and the pastorals (Wolter 1993:27-28).

2 Many of the newer sources on Colossians and Ephesians no longer debate the issue but simply summarise it and accept it as solved, for example Van Wyk 2015:2-3. Most do not offer new arguments. As I do not regard the issue as resolved, most of the sources used are ones that still debate the issue, whether new or older.

3 See Goswell's discussion on the implications of the hermeneutical move to the reader, which is considered to lead to the "death of the author" (2017:734), or the discussions on reader-response criticism in Davies (2013:11-35) and McKnight (1993:197-220).

4 For example, the sole reference to 1 Timothy in the work on Paul and the dynamics of power (Ehrensperger 2007:135), or the single reference to a Colossians text in Eichholz's Theology of Paul (1988:151).

5 There are, however, still scholars who argue differently. See Schweizer's discussion of the theory of Goodspeed and Knox that Colossians is based on an underlying genuine Pauline letter, but that it was heavily edited under the influence of the letter to the Ephesians (Schweizer 1976:25). 
Some of Paul's characteristic central theological concepts are also missing. As indicated in the introduction, this includes the "Holy Spirit" (Schweizer 1976:22). In Colossians 2:17 there is a reference to the law which is closer to the book Hebrews than to the genuine Pauline letters (Schweizer 1976:22), and there is no mention of justification, which Schweizer finds "almost unthinkable", particularly in the context of the Colossians discussion about upholding certain feast traditions (1976:22). Other typically Pauline terms or concepts absent in Colossians are $\alpha \mu \alpha \rho \tau i ́ \alpha(\sin )$ in the singular,

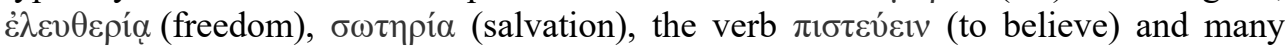
others (Wolter 1993:27). Some Pauline ideas are phrased in such a way that Lohse states that Paul cannot be the "direct or indirect" author of Colossians (Lohse 1968:254). For example, the letter speaks of the triumph of Christ not over sin, death and the law, but

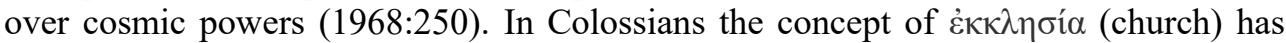
become much more all-encompassing, the place where Christ rules the world now (1968:251), which corresponds with the retreat of eschatology (1968:251). Thompson summarises the argument: "The problem is not that Colossians fails to treat a typically Pauline theme, but that Colossians fails to treat this theme in a typically Pauline manner" (Thompson 2005:3). The argument that the false teaching the letter attacks is Gnosticism, and therefore the letter must be late, (e.g. Baur 2003 [1873]: Vol 2,(9) has generally been refuted, but scholars still argue that a different church situation from that of the undisputed Paulines is presupposed (MacDonald 2000:18). MacDonald argues that Colossians and Ephesians were written in response to the death of the founder of the Pauline congregations, to help structure the movement after their loss (1988:85-92; 2000:8).

\section{The case for Pauline authorship of Colossians}

Despite the problems mentioned above, many scholars still argue that Colossians can best be explained as a Pauline letter. Various arguments have been put forward.

Firstly, there is a very close relationship between this letter and the generally undisputed letter to Philemon. It seems that the two letters were composed to be sent together. Colossians mentions "Onesimus, our faithful and dear brother" (Col 4:9), both letters are attributed to Paul and Timothy (Col 1:1 and Phm 1) and presume similar prison circumstances: Paul is in "chains" (Col 4:18), but has freedom to communicate with fellow prisoners and convey their greetings (Col 4:7-17). Most strikingly, the greetings overlap to a large extent. All the names in Philemon 23-24 also appear at the end of Colossians, (4:10-14): Epaphras, Mark, Aristarchus, Demas and Luke. The only differences are the reference to Jesus, who is called Justus in Colossians (4:11), and in Philemon Epaphras is named as a fellow prisoner, while in Colossians it is Aristarchus, which could be explained simply as a question of who knew who, ie which of these people would have been known to the different recipients of the letters. This direct repetition of names points to two letters written at the same time (Thompson 2005:5). This is disputed by Pokorný, who argues that Colossians must have been written later, because it is unlikely that the slave Onesimus would have travelled as far as Rome, so Philemon must have been written in Ephesus (Pokorný 1987:6), an argument disputed by Thompson (2005:6). ${ }^{6}$ Whatever the precise relationship between the two, if a later

6 Lohse argues that Colossians, if genuine, must have been written from Rome, and ultimately rejects Pauline 
author deliberately tried to make his letter sound Pauline, it would have been strange to have chosen the rather obscure letter to Philemon as base for the letter, rather than a more prestigious theological letter such as Corinthians or Romans. It also seems strange that such an author would have added comments about Mark to the greeting list when a gospel with that name was already circulating at the time. A pseudonymous author signing in Paul's "own hand" (4:18) seems to suggest deliberate falsification, when this was not necessary. While Philemon does have an "own hand" signature (Phm 19), many undisputed Paulines do not, so it would not have been necessary for the author of Colossians to include one. These points seem to indicate that Colossians is genuinely a companion letter to Philemon.

The second argument against a late composition of Colossians is that according to all indications, the city of Colossae was destroyed by an earthquake in the year $61 \mathrm{CE}$ together with its neighbor Laodicea (Schweizer 1976:23). While it seems that Laodicea was rebuilt, there are no further historical references to Colossae. This means the letter was either written during Paul's lifetime, or written to a place which no longer had a thriving congregation. Wilson, who argues for post-Pauline authorship, offers a reason for this: The author wanted to convey the impression of a letter written during Paul's lifetime, so he deliberately chose the congregation of Colossae as recipient: "A city in ruins and a church that no longer existed might have suited his purpose very well, since there would be nobody to expose the pseudonymity; but this again is conjecture" (Wilson 2005:18). ${ }^{7}$ However, such an argument sounds more like deliberate falsification than simple pseudonymity and is not convincing. Others dispute the complete destruction of Colossae (Wolter 1993:35).

Thompson argues for Pauline authorship and explains the lack of polemic with the fact that the congregation was not founded by Paul, and that Paul would have been more careful with his language to an unknown congregation (2005:3). She does acknowledge that this also applies to Romans, written in the typical Pauline style.

Proponents of Pauline authorship point to the incidences of Pauline phrases and ideas, for example the Christ-centredness of his theology and his focus on redemption on the cross (Col 1:9-20; Mcknight 2018:56-57). Differences in language and style and themes are explained by the different situation of the congregation in that certain favourite Pauline issues were not controversial in the congregation, and that a "different subject requires different words" (Hendriksen 1971:29), although this fails to explain the great shifts in language, style and ideas. ${ }^{8}$ It is also worth mentioning again that early church fathers accepted both letters as Pauline (Fowl 2012:18) and that these letters are included in the very earliest Pauline collections (Grizzle 2013:7).

The hypothesis for Deutero-Pauline authorship raises many new questions. MacDonald's argument (2000:8) fails to explain why a letter in response to the death of

authorship. He quotes Kaesemann, "if authentic, on the basis of content and style, as late as possible; if inauthentic, as early as conceivable" (1968:236; also, McKnight 2018:6). Wolter rejects the possibility that Colossians could have been written at the same time as Philemon, assuming that Philemon must have been written in Ephesus (Wolter 1993:30). However, other scholars argue that it would have been logical for an escaped slave to flee to Rome (see discussion in Wilson 2005:21).

See also Donelson (1996:10).

8 Similarities between Colossians and the other Pauline letters are both quoted to demonstrate that Paul could have been the author, as well as providing proof that someone else imitated Paul, because Paul would not have just "quoted himself" (Sanders 1966:44). 
Paul would have been written to a congregation he did not found and had never visited, and why it contains no reference at all to the brutal persecution and suffering that ended his life together with countless other Christians. It is difficult to imagine that there would be no mention of this persecution in a letter not long after the death of Paul. But of course this could have happened if it was written decades later, as other scholars argue (Pokorny 1987:15).

Many scholars who argue for a Deutero-Pauline origin argue for a "Pauline school" which tried to make the revered master's teachings fruitful for the next generation, a place "in which Paul's authority was certainly central, but where other associates and disciples participated in learning, instructing, and imitation of Paul's teaching" (MacDonald 2013:290-291, also 1988:124). Indeed, the existence of such a school is speculative, and if it existed, there must have been at least two, one producing Colossians and Ephesians and another one the pastorals. This raises many new questions. Did the "schools" produce only these few canonical letters and why not more? If there were more, what happened to those letters? Why did the early church accept letters with very different outlooks and arguments as Pauline? Was Paul really such an unquestioned authority figure in the contested space of the early church that writing in his name conferred immediate legitimacy, no matter in what form and on what subject? The Deutero-Pauline hypothesis solves some problems, but raises countless new questions, which generally have not been answered by those advocating Deutero-Pauline authorship.

\section{The secretary or co-worker hypothesis}

A compromise solution which may solve the contradiction of Pauline ideas expressed in non-Pauline ways, is the hypothesis that Paul may have made use of a secretary, or that Timothy may have had a larger than usual hand in drafting the letter. It is likely that Paul usually dictated his letters to a secretary, and only signed the greeting "in my own hand" (1 Cor 16:21). At the time writing consisted of a whole "spectrum - from taking dictation to authorized composition" (Hansen 2010:2). So it is possible that prison conditions prevented Paul from dictating the letter and he gave his secretary freedom to compose it. Lohse rejects the idea of a secretary as simply a scribe, arguing that this person must have been a theologian in his own right, who was decisively influenced by Paul, but he argues that Colossians must have been written later because the shifts are too great to even allow for "indirect" authorship (1968:254). ${ }^{9}$ However, others argue that the Timothy hypothesis best explains both the Pauline and the non-Pauline elements of Colossians (Dunn 1996:38, Schweizer 1976:26). This article will follow this argument for the following reasons:

Firstly, in several letters Paul lists co-workers together with himself as senders. This probably means he discussed the content of the letters with them, but then dictated them himself: Sosthenes in 1 Corinthians, Timothy in 2 Corinthians, Philippians and Philemon, Silas (or Silvanus) and Timothy in $1 \& 2$ Thessalonians. This means Timothy was involved in some way in the drafting of many of the undisputed Pauline epistles. Of

9 In his review of the commentaries, Hübner agrees with Lohse's critique of Schweizer's Timothy Hypothesis, which does not explain the "retreat of eschatology and the more advanced Christology and Ecclesiology (Hübner 2003:267). 
course, we cannot know how much "pure Paul" is in the undisputed letters (McKnight 2018:8). This raises the question of the reasons why Timothy had a freer hand than usual in actually writing the letter.

Secondly, Paul was in prison and Timothy was free to interact with people, travel to some extent (Phil 1:19), and have a sense of what was happening in the congregations. He would have realised if theological emphases shifted and might have been embroiled in arguments around Paul's teachings. He would have known how controversial Paul's teachings were particularly amongst Jewish Christians (as indicated in Col 4:11). He would probably have developed different theological emphases than his teacher, in spite of his continuing deep respect for Paul. This could have been out of an interest in fostering unity between Gentiles and Jews in the church.

There are several possible reasons why Paul might have given his trusted co-worker the go-ahead to write the letter in both their names. The first two possible reasons which will be discussed here, are plausible, but do not explain the relationship with Ephesians, nor why Timothy would omit characteristic Pauline terms. The third, the hypothesis of this article, tries to find a possible reason for both the characteristics of Colossians and Ephesians.

The first reason could be a less sympathetic prison guard who restricted Paul's visiting hours for a while and made it possible to dictate the short letter to Philemon but not the longer letter to the Colossians. This would have been discussed with Paul and then written by Timothy. ${ }^{10}$ A second possible reason, also related to time pressure, could be that Tychikus needed to leave soon to ensure a safe passage across the Mediterranean (assuming these letters were written in Rome), and that time pressure dictated writing into the night, when prison doors would have been shut. Paul could still have signed it in the morning before Tychikus' departure. The problem is that an argument for Pauline authorship of Ephesians would then require a similar scenario, which is unlikely.

\section{Co-workers trying to build unity}

This article wants to explore another hypothesis: Paul was experienced as controversial, and Timothy was trying to help build unity between factions and make Paul's teachings more socially acceptable to the congregations.

We know that co-workers did indeed try to do damage control in situations of conflict with Paul. Paul himself admits this in 2 Corinthians 2:1-4, 7:5-7, where it seems Titus acted as a mediator. Acts 15:36-41 indicates that conflicts with Paul could be sharp. We also know that there was a letter to the Laodiceans that was lost ( $\mathrm{Col} 4: 16)$. None of the attempts to link it to other letters have been convincing. ${ }^{11}$ The fact that this letter to a congregation was not conveyed while the short letter to the individual Philemon was, raises the question if perhaps it was deliberately not copied and passed on to other congregations because it was too controversial. We know that there may have been

10 Schweizer simply argues that "prison conditions" might have made it impossible for Paul to write the letter himself, but this in itself does not answer many of the puzzling questions (1976:25).

11 Marcion already equated the Ephesian letter with the letter to the Laodiceans (Taylor and Reumann 1985:18) and others have done so since, (see discussion in Wolter 1993:220) or identify it with the letter to Philemon (Goodspeed 1951:285) or even Hebrews (see discussion in Dunn 1996:287). The arguments that Ephesians must be later than Colossians makes this unlikely - see later discussion. Very few scholars take the other two suggestions seriously. 
another letter which is not in the Canon, the letter referred to in 2 Corinthians $2: 3$. We can only speculate about the reasons for the probable controversial nature of the letter to the Laodiceans, but it is likely that it was related to slavery. In the Colossians letter, Onesimus is mentioned as a "dear brother" (4:9), while the same letter introduces the household code, in which slaves are called on to "submit" (3:22). In this code (Col 3:184:1), four verses centre on slaves, only one on all the other role players. This indicates that there may have been controversy around the slave Onesimus. Sending back a runaway slave and asking the owner to receive him as a brother (implying that he should not be punished), could have been seen as a dangerous precedent by slave owners. ${ }^{12}$ Suggesting that Onesimus should be set free would have been even more controversial, if this is what is implied in Philemon 21: "I am writing to you, knowing that you will do even more than I say" (NRSV). This is argued by many commentators (e.g. Wilson 2005:364). While these may have been dangerous precedents, they would still generally have upheld the social order. However, a really explosive controversy would have been generated if Paul was initially unwilling to send Onesimus back, but harboured the fugitive slave, calling him brother. The fact that he does not ask Philemon to forgive Onesimus, or explain that he is a transformed man since his conversion, may show that he sympathised with Onesimus and understood his reasons for running away. If he in any way voiced this, this could have culminated in the controversial letter to the Laodiceans ${ }^{13}$ and the need for damage control in Colossians.

The hypothesis of this article is that Colossians was written after a massive controversy around the slave Onesimus, and that Paul's co-workers, including Timothy and possibly Tychikus, persuaded Paul to send Onesimus back to his owner, and to allow the owner to decide about what should happen to him. In the letter to Philemon Paul pleads very personally for Onesimus and asks his owner to receive him like a brother (Phm 16). The accompanying letter (Colossians) could have been written to help calm the upheaval in these congregations. It was written to the neighbouring congregation close to Laodicea, ${ }^{14}$ and only indirectly addresses the controversy, but there is a direct request for a letter exchange with Laodicea, and greetings to that congregation. In this way Paul did not have to directly retract anything he wrote. It is obviously impossible to reconstruct what exactly the controversy was about, but the words of Paul in Galatians $3: 28$, Colossians $3: 11$ and even in the letter to Philemon (Phm 16) strongly suggest that he would have supported manumission for slaves who converted to Christ. Paul would not have supported subverting the whole social order, particularly because he believed

12 It is beyond the scope of this article to consider suggestions that Philemon may not have been an escaped slave (as argued for example by Callahan 1993). Here the majority scholarly position is accepted, that Onesimus ran away, regardless of whether he deliberately sought out the help of Paul. For a discussion of the different positions, see Tolmie 2009.

13 It is far beyond the scope of this article to prove this hypothesis, which has to remain speculative. This article can only question if the facts in front of us can be explained by such a hypothesis. It has been commented repeatedly that the household code in Colossians seems to be mainly aimed at slaves, although reasons offered for this differ, depending on how scholars see the association with the letter to Philemon (Dunn 1996:259).

14 It is not clear which congregation Philemon was from. Here the argument that Archippus is mentioned at the end of the section on Laodicea (Col 4:17) convinces more than the argument that Onesimus and Philemon must have been from Colossae because Paul speaks of Onesimus as "one of yourselves" (Schweizer1976:27). The communities were close together (Wilson 2005:3) and must have had a fair amount of contact. This means that neither conclusion is crucial to the argument. 
that the "time was growing short" (1 Cor 7:29). But in this chapter in 1 Corinthians where he encourages everyone to "remain in the condition in which you were called" (7:20 NRSV), he expressly says to slaves "if you can gain your freedom, do so" (7:21 NIV). ${ }^{15}$ Even if this was not a programme pursued actively and consistently by Paul, every manumission would have strengthened the sentiments expressed in Galatians 3, though it would still have been within the established order. Of course, supporting freedom for a runaway slave, would have been much more of a threat to the established social order.

It was probably not only the slavery issue which generated controversy, but the whole "freedom" based theology of Paul, which also threatened to undermine other social hierarchies, such as that between men and women. Therefore the aim of the letter to the Colossians would have been to present a less controversial Pauline theology, which meant writing in a more measured and less polemical style, and leaving out controversial terms such as the "Holy Spirit" as equaliser in a congregation, "justification apart from works of the law" and "sin", which everyone is equally guilty of. It includes the call for social order through the household codes. The emphasis is on the centre, on Christ the Lord of all and the reason for unity.

Arguments against the "Timothy Hypothesis" are that the letter is too dissimilar for Paul to be even an indirect author, and that he would never have allowed someone to draft a letter in his name completely independently (Pokorny 1987:15). However, if this hypothesis is correct, Paul would have had little choice. He was dependent on his coworkers and risked losing all influence in some congregations if he showed himself unwilling to compromise. Also, he had shown in his undisputed letters that he could distinguish between matters which were at the heart of the gospel, about which there could not be compromise, and those matters which allowed for differences of opinion (1 Cor $7: 10-14,1$ Cor 8 ). In this case he might have been persuaded that it was better to encourage slaves to wait for their reward in heaven (Col 3:24) than to risk violence against them if they rebelled or were encouraged to run away.

This is, of course, only a hypothesis, and needs to prove its value as to whether or not it can help explain not only Colossians, but also Ephesians and the letter to Philemon (which will not be further discussed in this article). ${ }^{16}$ It also needs to prove its plausibility for interpreting the difference between the specific passages.

One point which may support this hypothesis is the question of the purpose of the letter of Colossians. Most scholars argue that the reason for writing Colossians was to refute a dangerous false teaching (Lohse 1968:28; Pokorny 1987:25). However, there is very little agreement on what exactly this false teaching was. In 1973 an exhaustive study by JJ Gunther listed 44 different suggestions from $19^{\text {th }}$ and $20^{\text {th }}$ century scholars as to what this dangerous teaching was (O’Brien 1982: xxxi). Some scholars question whether the reason really was to combat a particular teaching or more general dangerous tendencies (see discussion in MacDonald 2000:11-12). The lack of polemic and argumentative style in Colossians in particular is repeatedly noted, one of the many

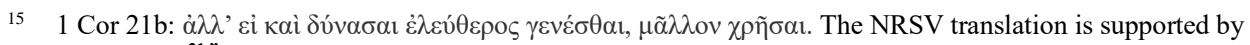
few others: ${ }^{21}$ "Were you a slave when called? Do not be concerned about it. Even if you can gain your freedom, make use of your present condition now more than ever". It adds in a text note: "Or avail yourself of the opportunity". The text note is the much more likely and more widely supported reading.

16 Hendriksen quotes John Knox: "The whole of Colossians is more or less overshadowed by Paul's concern about Onesimus" such as his plea for tenderness of heart (3:12-14) (Hendriksen 1971:23). 
reasons why scholars call its Pauline authorship into question (Pokorny 1987:2). All this may support the hypothesis that the primary purpose of the letter to the Colossians was not to attack a false teaching at all, but to defend the position of Paul and to soothe troubled waters. In the context in which the letter was written there were many dangers to warn about, but no single one of them seems to have been of overriding concern.

\section{Authorship debate - Ephesians Arguments for basing Ephesians on Colossians}

Whatever one's theory on the origin of Colossians, it is very clear that the author of Ephesians must have known Colossians. There are many similarities, sometimes verbatim, like, for example, the references to Tychikus in Colossians 4:7-8 and Ephesians $6: 21-22,{ }^{17}$ and there are passages with only minor differences, such as Colossians 3:204:1 and Ephesians 6:1-9. The general structures of the letters are similar, such as the fact that in both letters the household codes immediately follow the section on worship (Col 3-4, Eph 5-6). However, there are also many developments and differences and enough shifts in the message that some scholars do not agree that Ephesians was written by the same author as Colossians (Schnackenburg 1982:29). There is no agreement on whether the author of Ephesians had a written copy of Colossians. Schnackenburg argues that it is enough to assume he knew it so well that words and sentence structures from this letter freely "flowed into his pen" (1982:29, see also Mitton 1976:12), but many others argue for literary dependence (Taylor and Reumann 1985:12). The shifts in style further removes Ephesians from Paul. In most of the cases where there are parallels between Ephesians and Colossians, the Ephesians version seems to be the more developed and longer one (e.g. Col 3:1-4:6 and Eph 4:1-6:20), making its later origin almost universally accepted. Another hypothesis argues that the two authors were Pauline disciples of the same schools, participating in the same discussions, therefore sharing the same ideas and language (Best 1997:93-94). However, the similarities in words and structure are too numerous to make this likely. Literary dependence will be argued here. However, there is undoubtedly a shift in style and theology. The language is quite calm and even liturgical, or in the style of a wisdom pronouncement (Schnackenburg 2013:22). Other ways in which Ephesians differs from Colossians, are the absence of personal greetings, and that Paul alone is the sender. Several of the themes missing in Colossians are included in Ephesians, such as salvation by grace (Eph 2:8), or the Holy Spirit (1:13), but they are still presented in markedly different ways to the undisputed Paulines, which Schnackenburg calls "watered down" (Schnackenburg 2013:23). Many scholars, even some of those who consider Colossians as genuinely Pauline, dispute Pauline authorship of Ephesians. The style is markedly different, and scholars argue that it is unlikely that Paul would have quoted himself verbatim so extensively. It is more likely that another author did (Schnackenburg 1982:26). Lindemann argues that Ephesians is a deliberately reworked version of Colossians (1985:12).

According to Fowl (2012:20), this parallel convinces many scholars of the literary dependence of Ephesians on Colossians, but this is not universally accepted. Best uses specific grammatical and stylistic characteristics of these two passages to argue that the dependence could be the other way around (1997:78-79). 


\section{A general letter to congregations}

There is nothing in the letter indicating it was written to a congregation intimately known by Paul, and it has the characteristics of a general circular letter (McDonald 2008:17). Text-critically it is clear that the heading "Ephesians" was added at a late stage. \&́v 'E $\varphi \varepsilon \dot{\sigma} \sigma \omega$ is missing in version P46 and in the original versions of Sinaiticus and Vaticanus and some other later manuscripts (6 and 1739, dated $8^{\text {th }}$ and $10^{\text {th }}$ centuries) (Nestle Aland). Marcion is also cited as an early witness in the text-critical apparatus, as he argued that this was the letter to the Laodiceans (Schnackenburg 1982:37). The letter also lacks any reference to the situation of the Ephesian congregation, which was founded by Paul, or any personal greetings, which is particularly surprising if it was modelled on Colossians. There is no consensus about what the purpose of Ephesians could have been, neither from those who support Pauline authorship nor from those who argue for Deutero-Pauline authorship. However there is consensus that unity is a central theme in the letter (Beker 1991:70; Mitton 1976:28).

\section{If the hypothesis above is correct, what might this mean for Ephesians?}

Assuming for a moment that Timothy generally formulated the letter to the Colossians to make Paul's message more acceptable to the congregations, what might this mean in terms of the authorship of Ephesians? What can explain both the similarities and the differences between the two letters? One can assume that it would not have been an easy process to find formulations that both Paul and the co-workers were happy with. As it was likely that such a situation could arise again, it would have seemed wise to keep a copy of the letter which represented a hard-won first consensus. However, it is likely to have been an uncomfortable consensus, as so many of the themes at the heart of genuine Pauline theology were left out.

The hypothesis of this article is that the origin of the letter to the Ephesians lies in this discomfort with the compromise of the letter to the Colossians, which simply left out controversial Pauline phrases. This led to an attempt to formulate a letter which set out the Pauline message in a way that could be heard and accepted by both the Jewish and the Gentile Christians in the young congregations. It is possible that more co-workers than just Timothy had a hand in workshopping the formulations in the letter to the Ephesians, and that they deliberately drew on common liturgical traditions to portray Paul's message as part of mainstream Christian teaching. Because Ephesians is likely to have been about "saving", the message of Paul in a time when he was increasingly isolated, especially from Jewish Christians ( $\mathrm{Col} 4: 11$ ), it was important to put just his name in the title, even though this was actually more of a joint effort. ${ }^{18}$

Trying to prove that Paul's message was not a threat to the good order in congregations, would inevitably have meant "watering down" Paul's viewpoints. So "justification by faith apart from the works of the law" (Rom 3:28) became "salvation by grace for good works" (Eph 2:8-10). The Holy Spirit became the "Spirit of Wisdom and revelation" (1:17), not concerned with breaking down social hierarchies but with guaranteeing good and ethical Christian living and "grieved" by unethical behaviour

18 The care that was taken in conveying Paul's thought is set out by Goodspeed, who argues that Ephesians has references to all nine letters and was composed deliberately as an introduction and summary of the Pauline corpus (1951: 286). However, his theory is disputed as there is no evidence of the existence of a collection of Pauline letters headed by the letter to the Ephesians as indeed acknowledged by the author (285). 
(4:30). The interest of unity between Jewish and Gentile Christians is a prominent theme in Ephesians (e.g. 2:14-18) and would have been the overriding concern of those drafting the letter. Unity is a concern throughout the undisputed Paulines too, as argued extensively by Hansen (2010:200-203), but it seems that the Jewish-Gentile unity came at the expense of slave-freedperson and male-female unity with their clearly differentiated power relations (Eph 5:22-6:9). It is clear that those drafting Ephesians drew heavily on the already workshopped formulations in Colossians, but their interest went far beyond simply reproducing that letter. They were using the consensus formulations to express different theological ideas. This rather strange manner in which Ephesians uses Colossians has been remarked on by scholars. Best, arguing against direct literary dependency of one on the other writes: "Authors do not search the documents of other writers to find suitable words at diverse points in them which they can draw together to express their own ideas" (Best 1997:76). This article argues that the group who authored Ephesians did precisely that. They found consensus formulations and words in Colossians which could be used to present a theology different from that presented in the first document. The fact that the meaning of the words and the phrases sometimes shifted, ${ }^{19}$ was not a problem if the same authors were involved, trying to improve on their first attempt. Sellin, who motivates dependence of Ephesians on Colossians, which he sees as Deutero-Pauline, points to the "remarkable" fact that Ephesians is closer to the genuine Pauline letters than the document it depends on $(2008: 56){ }^{20}$

It is likely that the carefully thought through formulations of the circular letter did indeed manage to promote reconciliation between those supporting Paul and those who saw his ideas as dangerous. However, at the same time the letter solidified an early church trend towards hierarchy and authority. While it must have been sent to many congregations, it was most likely the Ephesian congregation, who were very loyal to their founder, Paul, who made it their own, and were active in preserving it (also not having any other Pauline letters directly addressed to them). For this reason, it probably later became known as the letter to the Ephesians. Its importance is demonstrated by its position before the other prison letters in collections.

\section{The Word and the Spirit in Colossians 3:16 and Ephesians 5:18-19 Colossians}

As has been argued above, the letter to the Colossians deliberately omits references to the Holy Spirit while retaining the less controversial word "spiritual". If the hypothesis is correct, it seems this term was understood by the congregations as a threat to good order in the Christian church. The less threatening emphasis on the "Word" is understandable in this context.

Neither the Pauline nor the Post-Pauline hypotheses give a convincing reason for the absence of key Pauline terms in the whole letter. Those who argue for Pauline authorship,

\footnotetext{
19 For example, in Colossians, $\pi \lambda \eta \dot{\rho} \omega \mu \alpha$ (fullness) refers to Christ (1:19), and in Ephesians it refers to the church (1:23). There is a much stronger emphasis on ecclesiology in Ephesians (Schnackenburg 1982:28).

20 In the original: "Trotz der engen Anlehnung an den älteren Kol hat der Eph erstaunliche Übereinstimmungen mit den genuinen Paulusbriefen. In manchem ist er Paulus noch näher als seine Vorlage, der (für die Meinung des Verfassers des Eph sebstverständlich von Paulus verfasste) Kolosserbrief' (Sellin 2008:56).
} 
argue from a changed situation, but a changed situation does not normally lead to a completely changed theology. This leads many scholars to reject Pauline authorship.

The Deutero-Pauline authorship hypothesis also does not offer an adequate explanation why a post-Pauline author would write a letter in the name of Paul, carefully copy personal greetings and details from the letter to Philemon, but not include key Pauline terms. If this author did not agree with key aspects of Paul's theology, why did he base his letter on Paul at all? It is likely that important followers of Paul would still have been alive when Colossians was written. Would they not have raised objections to the misuse of Paul's name? In what circumstances would such a letter have been accepted as a genuine attempt to be true to Paul's intentions in changed circumstances (the usual explanation of the intention of pseudepigrapha) (Pokorny 1989:11)? Of course, other important Pauline terms and ideas are present (Wolter 1993:31), so this author could have had a particular interpretation of the essence of Paul's message. ${ }^{21}$

In this specific verse, however, one does not need to argue about the "absence of the Spirit". Making the "Word" central in a passage about early Christian worship makes sense in all three contexts.

\section{Ephesians}

If the hypothesis is correct, it would have been important for the group who drafted the letter to re-introduce key Pauline terms, but in ways which would be acceptable to readers and not cause offence.

The reintroduction of the Spirit in the Ephesians text is understandable in the context of worship, but it is very clearly reintroduced as an entity that does not disturb the good order of worship but enhances it. It is contrasted to being "drunk on wine" (Eph 5:18). Commentators speculate on this sudden (or abrupt) introduction of the theme of drunkenness (Fowl 2012:177), which would fit more naturally in the catalogue of vices at the beginning of chapter 5. If it was a particular problem in the congregations, it probably would have been treated more extensively. Schnackenburg also argues that

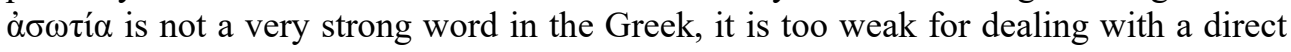
problem but fitting for addressing a general heathen lack of morality outside the congregation (1982:241). He does not offer a satisfactory reason why it is specifically introduced here. While Fowl points out that "the states of alcoholic and of religious intoxication were often compared" (2012:177), it is unlikely that Ephesians refers to enthusiasm. It is more likely that the juxtaposition of "drunk with wine" to "filled with the Spirit" is a deliberate strategy of reintroducing the Pauline emphasis on the Holy Spirit while making it clear that it contributes to rather than endangers good order in the congregation, especially during worship.

Other references to the Spirit in Ephesians bear out this pattern: In Ephesians 1:17 Paul prays for the recipients to be given a "spirit of wisdom and of revelation", in 4:4 the Spirit is mentioned in the context of patience and love, "eager to maintain the unity of the Spirit in the bond of peace". In 4:29 and 30 the Spirit is mentioned in the context of

21 Van Aarde argues that the author of Colossians was a "change agent" who saw himself in the tradition of Paul, but went beyond Paul, both in showing the newness of the life in Christ, and also accommodating it to the Greco-Roman reality, in the household codes. He does not indicate how these two relate to each other (2017:8). 
"evil talk" which is contrasted with "edifying" talk. The recipients should not "grieve the Spirit of God". The Spirit is also the one who is the guarantor of the authority of the apostles and the prophets, as the "mystery of Christ... has now been revealed by the Spirit of God" (Eph 3:4-5).

These verses all contrast with the more controversial line by Paul in Galatians: "But if you are led by the Spirit you are not under the law" (Gal 5:18). However, they are compatible with many of Paul's other statements about the Spirit, such as Romans 8:6, "the mind controlled by the Spirit is life and peace" and Gal 5:22-23, "But the fruit of the Spirit is love, joy, peace, patience, kindness, goodness, faithfulness, gentleness and

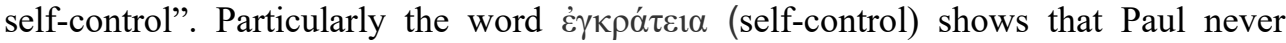
intended freedom to be a recipe for lawlessness. However, how far such freedom could be taken, would be bitterly disputed in the following decades.

Some scholars who dispute Pauline authorship of both epistles comment on the absence of the Spirit in Colossians (Schweizer 1976:22), but there is little comment on the fact that it is reintroduced in Ephesians. If Ephesians was written by a DeuteroPauline author, it would have been one who knew Paul well enough to have understood that Colossians was not a typical Pauline letter, and who felt the need to rectify this (see Lindemann's argument that the author of Ephesians "reworked" Colossians, 1985:12). But that raises the question why he would have then still based his letter on Colossians rather than on a more "typical" Pauline letter.

There is also no explanation for the absence and reintroduction of Pauline terms by scholars who defend Pauline authorship of both.

If one accepts the hypothesis above, it means that the "Spirit" was deliberately omitted in Colossians and reintroduced in a controlled way in Ephesians. One could thus argue that Ephesians is more "Pentecostal" than Colossians, but the Spirit in Ephesians is not one that allows uncontrolled and spontaneous enthusiasm, and the freedom of worshipers to do as they please, but one that draws people together in unified, ordered worship.

\section{Implications for contemporary worship}

Whatever one says about the authorship debate and the possible reasons for writing the two epistles, both letters, but especially Ephesians, have a clear interest in building unity. If the hypothesis is correct, then the overriding concern of both the authors of Colossians and Ephesians was rebuilding unity and trust after conflict and misunderstandings, though the strategy followed in the two cases differs. This left the congregations strengthened, but some of Paul's theological emphases weakened, particularly his strong emphasis on freedom and justification. The following decades would see a rise in the tension between freedom and equality on the one hand, and unity built by submission to authority on the other, which gained impetus through these two letters. This is a struggle which still plays out in churches and denominations. There is much to be learnt from the formulations in Ephesians which try to keep the two in balance.

While the phrase "psalms, hymns and spiritual songs" in itself cannot be taken as a decisive call for blended worship, as the words are used interchangeably in biblical texts and do not refer to separate categories (O'Brien 1999:395), the entire context of the passages calls for unity of and tolerance for the different groups in the congregation the Gentiles and the Jews. It calls for orderly worship which allows for expressions of 
the Holy Spirit, while keeping a focus on community and mutual teaching and upliftment. The fact that the authors of Ephesians copied this three-fold formula from Colossians, shows that they found it useful for building unity in worship. While there will be Christians who prefer the Word-centred formulation in Colossians and others who prefer the Spirit-centred formulation in Ephesians, this too can be a sign that diversity can be celebrated within a unified church of God.

\section{Conclusion}

The hypothesis developed in this article is that both the letters to the Colossians and Ephesians were an attempt to make Paul's theology more acceptable to the congregations of Asia Minor. This hypothesis makes sense of the differences between the two letters as well as the possible reason for Colossians' close relationship with the letter to Philemon. However, this hypothesis will need to be tested on more parallel texts in the two letters to see whether this theory can explain the documents as they have been transmitted to us.

\section{BIBLIOGRAPHY}

Baur, F.C. [1873], 2003. Paul, the apostle of Jesus Christ-His life and works, his epistles and teachings, Two volumes in one. Peabody: Hendrickson Publishers.

Beker, J.C. 1991. Heirs of Paul-Paul's legacy in the New Testament and in the church today. Minneapolis: Fortress Press.

Best, E. 1997. Who used whom? The relationship of Ephesians and Colossians, New Testament Studies 43:72-96.

Callahan, A.D. 1993. Paul's epistle to Philemon: Toward an alternative argumentum, The Harvard Theological Review, 86(4):357-376.

Costa, T. 2013. Worship and the risen Jesus in the Pauline Letters. New York: Peter Lang.

Donelson, L.R. 1996. Colossians, Ephesians, First and Second Timothy, and Titus. Westminster: John Knox Press.

Dunn, J.D.G. 1996. The Epistles to the Colossians and to Philemon. Grand Rapids: William B. Eerdmans.

Ehrensperger, K. 2007. Paul and the dynamics of power - Communication and interaction in the early Christ-movement. In Goodacre, M. (ed), Library of New Testament Studies Vol 325. London: T \& T Clarke.

Eichholz, G. 1988. Die Theologie des Paulus im Umriß. Neukirchen-Vluyn: Neukirchener Verlag.

Davies, E.W. 2013. Biblical criticism - A guide for the perplexed. London: Bloomsbury.

Fowl, S. 2012. Ephesians, a commentary. Westminster: John Knox Press.

Goodspeed, E.J. 1951. Ephesians and the first edition of Paul, Journal of Biblical Literature 70(4):285-291.

Goswell, G. 2017. Authorship and anonymity in the New Testament writings, JETS 60(4):733-49.

Grizzle, T. 2013. Ephesians, Pentecostal Commentary Series. Dorset: Deo Publishing. 
Hansen, B. 2010. All of you are one - The social vision of Galatians 3.28, 1 Corinthians 12.13 and Colossians 3.11. In Goodacre, M. (ed), Library of New Testament Studies Vol 409. London: T \& T Clark.

Hay, D.M. 2000. Colossians. Nashville: Abingdon Press.

Hendriksen, W. 1971. A commentary on Colossians and Philemon. London: Banner of Truth Trust.

Hooker, M.D. 2003. Colossians. In Dunn, J.D. (ed), Eerdmans commentary on the Bible. Michigan: William B. Eerdmans.

Hübner, H. 2003. Die diskussion um die deuteropaulinischen briefe seit 1970. Der Kolosserbrief (I), Theologische Rundschau Neue Folge 68(3):263-285.

Lindemann, A. 1985. Der Epheserbrief, Zürcher Bibelkommentare. Zürich: Theologischer Verlag.

Lohse, E. 1968. Die Briefe an die Kolosser und an Philemon. Göttingen: Vandenhoek \& Ruprecht.

MacDonald, M. 2000. Colossians and Ephesians, Sagina Sacra Series Vol 17. Collegeville: Liturgical Press.

MacDonald, M. 1988. The Pauline churches - A socio-historical study of institutionalization in the Pauline and Deutero-Pauline writings. Cambridge: Cambridge University Press.

MacDonald, M. 2013. Paul's portrait in Colossians and Ephesians, Bible Today 51(5):288-294.

Marshall, I.H. 2003. Ephesians. In Dunn, J.D. (ed), Eerdmans commentary on the Bible. Michigan: William B. Eerdmans.

McFarland, I.A. 2000. A canonical reading of Ephesians 5:21-33 - Theological gleanings, Theology Today. Available online: https://doi.org/10.1177/004057360005700304.

McKnight, E.V. 1993. Reader-response criticism. In McKenzie, S.L. and Haynes, S.R. (eds), To each its own meaning - An introduction to Biblical criticism. London: Geoffrey Chapman.

McKnight, S. 2018. The Letter to the Colossians. Michigan: William B Eerdmans.

O’Brien, P.T. 1982. Word Biblical Commentary Vol 44 - Colossians, Philemon. Waco: Word Books Publisher.

Pervo, R.I. 2010. The making of Paul-Constructions of the Apostle in Early Christianity. Minneapolis: Fortress Press.

Pokorný, P. 1987. Der Brief des Paulus an die Kolosser. Berlin: Evangelische Verlagsanstalt.

Porter, S.E. and Clarke, K.D. 1997. Canonical-critical perspective and the relationship of Colossians and Ephesians, Biblica 78(1):57-86.

Sanders, E.P. 1966. Literary dependence in Colossians' author(s), Journal of Biblical Literature 85(1):28-45.

Schnackenburg, R. 1982. Der Brief and die Epheser, EKK Vol 10. Einsiedeln: Benziger Verlag.

Schnackenburg, R. and Schweizer, E. 2013. Der Brief an die Epheser / Der Brief an die Kolosser - Evangelisch-Katholischer kommentar zum Neuen Testament. Neukirchen-Vluyn: Neukirchener / Patmos Verlag.

Schweizer, E. 1976. Der Brief an die Kolosser - Evangelisch-Katholischer Kommentag 
zum Neuen Testament. Zürich/ Neukirchen-Vluyn: Benzinger / Neukirchener Verlag.

Sellin, G. 2008. Der Brief an die Epheser - Meyers Kritisch-Exegetischer Kommentar über das Neue Testament. Göttingen: Vandenhoek \& Ruprecht.

Taylor, W.F. and Reumann, J.H.P. 1985. Ephesians, Colossians - Augsburg Commentary on the New Testament. Minneapolis: Augsburg Publishing House.

Thompson, M.M. 2005. Colossians and Philemon. Grand Rapids: William B. Eerdmans.

Tolmie, D.F. Onesimus - 'n wegloopslaaf? Oor die ontstaansituasie van die Filemonbrief, Verbum et Ecclesia 30(1):279- 301.

Van Aarde, A.G. 2017, "By faith alone" (undivided loyalty) in light of change agency theory: Jesus, Paul and the Jesus-group in Colossae, HTS Teologiese Studies/Theological Studies 73(3), a4355. Available online: https://doi. org/10.4102/hts.v73i3.4355.

Van Wyk, B. 2015. Die verhouding tussen Kolossense en Efesiërs as 'n sinoptiese probleem, HTS Teologiese Studies/Theological Studies 71(3), Art. \#3067. Available online: http:// dx.doi.org/10.4102/hts.v71i3.3067.

Wetmore, H. 2012. What songs shall we sing? Available online: http:/gatewaynews.co.za/which-songs-shall-we-sing.

Wilson, R.M. 2005. A critical and exegetical commentary on Colossians and Philemon. London: T \& T Clark International.

Wolter, M. 1993. Der Brief an die Kolosser, Der Brief an Philemon. Gütersloh: Gerd Mohn. 